\title{
Virus susceptibility and resistance of Hungarian pepper varieties
}

\author{
Horvâth J. ${ }^{1}$, Kazinczi G. ${ }^{1}$, Takács A. ${ }^{1}$, Pribék D. ${ }^{1}$, Bese G. ${ }^{1}$, \\ Gáborjányi R. ${ }^{2}$ and Kadlicskó S. ${ }^{1}$ \\ ${ }^{I}$ University of Veszprém, Georgikon Faculty of Agriculture, Department \\ Plant Pathology and Virology, \\ H-8361 Keszthely, P.O. Box 71, Hungary \\ ${ }^{2}$ Plant Protection Institute, Hungarian Academy of Sciences, \\ H-1525 Budapest, P.O. Box 102, Hungary
}

Key words: pepper, varieties, virus susceptibility, resistance

\begin{abstract}
Summary: The aim of our study was to examine susceptibility or resistance of 18 pepper varieties to four viruses [tobacco mosaic tobamovirus (TMV), sowbane mosaic sobemovirus (SoMV), NTN strain of potato Y potyvirus (PVYNTN) and cucumber mosaic cucumovirus (CMV). Out of the 18 varieties, 13 were resistant to CMV infection. Thirteen varieties were susceptible to TMV, while five ones (Dabora F1, Brill F1, Fehérözön Synthetic, Ciklon F1, Cecil F1) showed only local hypersensitive reaction. All of the tested pepper varieties showed resistance to SoMV. Eight varieties (Tuba, Fehérözön Synthetic, Boni, Alba Regia, Korona, Édesalma, Cecil F1, Star) were found to be resistant to PVYNTN. Out of the examined varieties five (Boni, Alba Regia, Korona, Édesalma, Star) were resistant to three viruses (SoMV, CMV and PVYNTN). Only one (Cecil F1) displayed complex, extreme resistance to SoMV, PVYNTN, CMV and hypersensitive reaction to TMV, therefore this hybrid is very important in pepper breeding and growing for virus resistance.
\end{abstract}

\section{Introduction}

Peppers (Capsicum spp.) originating in Mexico, Southern Peru and Bolivia are now grown world-wide under various environmental and climatic conditions (Pickersgill et al. 1979). Last decades vegetable growing under glassand foil-house conditions achieved considerable results in Hungary. Forced pepper play the most important role in this respect. The consumption of our traditionally national product - sweet pepper - increases not only in Hungary but abroad as well; therefore changing of eating habit creates good export possibilities for Hungarian primeur pepper (Budai et al. 1996). Besides this, red pepper is an important national product of Hungary.

Among pathogens, viruses cause the most important diseases of paprika. Virus diseases are one of the major limiting factors in successful pepper cultivation (Martelli \& Quacquarelli, 1983, Horváth, 1986b, Duriat, 1996). The extent of infection varies between 20 and $60 \%$, and 5-40\% yield losses may occur due to virus infection. The species of Capsicum genus are known as natural and artificial hosts of 55 and 44 plant viruses, respectively (Horváth, 1981, Horváth, 1986a, Green \& Kalloo, 1994, Edwardson \& Christie, 1997). Response of different pepper varieties, breeding lines, the different Capsicum species and accessions to virus infections have been extensively studied (Horváth, 1986c, Mijatovi, 1997, Castagnoli et al., 1997, Sudarsono et al., 1998, Wang et al., 1998). Out of them new sources of resistance have been found, which could be used for pepper breeding programs (Sowell, 1982, Lane et al., 1997). Viruses and other pathogens often occur in complex infection, increasing injuries (Gáborjányi et al., 1997, 1998a, Kazinczi et al., 1998a,b,c). In Hungary 13 viruses have been isolated from infected pepper plants so far. The extremely stable, mechanically transmitted tohamoviruses are found to be the major problems under cover conditions, while the dominance of the aphid transmitted cucumo-, potyand alfamoviruses were demonstrated in the open fields (Salamon, 1996). Recently new viral diseases of pepper, named: pepper yellow vein mosaic and pepper yellow line and ring pattern have been occurred under cover in Hungary and abroad. In spite the fact, that the etiology of these diseases is intensively studied, viruses have not been exactly identified so far (Fletcher et al., 1987, Rast, 1988, Salamon \& Szürke, 1990, Salamon \& Némethy, 1995, Burgyán \& Szittya, 1996, Szittya \& Burgyán, 1996). Due to a regular survey has been made since 1970's in South-Hungary, it was confirmed that tobacco mosaic tobamovirus (TMV), tomato mosaic tobamovirus (ToMV), cucumber mosaic cucumovirus (CMV), alfalfa mosaic alfamovirus (AMV) 
and potato $\mathrm{Y}$ potyvirus (PVY) are the most widespread under covers causing severe yield losses, particularly in complex infections (Kiss, 1996). First descriptions of pepper pathogen viruses in Hungary are listed in Table $I$.

Table 1 First descriptions of pepper pathogen viruses in Hungary

\begin{tabular}{|l|l|}
\hline Viruses & References \\
\hline Cucumber mosaic cuctumovirus (CMV) & Szirmai (1941) \\
Alfalfa mosaic alfamovirus (AMV) & Szirmai (1944) \\
Tobacco mosaic tobamovirus (TMV) & Szirmai (1950) \\
Potato X potexirus (PVX) & Szirmai (1950) \\
Potato Y potyvirus (PVY) & Horváth (1967) \\
Tomato aspermy cucumovirus (TAV) & Beczner et al. (1979) \\
Broadbean wilt fabasirus (BBWV) & Salamon et al. (1980) \\
Dulcamara yellow fleck tobamovirus (DYFV) & Salamon et al. (1987) \\
Tomato mosaic tobamovirus (ToMV) & Csilléry et al. (1983) \\
Tomato spotted wilt tospovirus (TSWV) & Gáborjányi et al. (1995) \\
Henbane mosaic potyvirus (HeMV)* & Gáborjányi et al. (1997) \\
Sowbane mosaic sobemovirus (SoMV)* & Gáborjányi et al. (1997) \\
Pepper mild mottle tobamovirus (PMMV) & Kálmán \& Gáborjányi \\
& (2000) \\
\hline
\end{tabular}

*serologically detected viruses

First of all 'újhitûség' disease of pepper was described by Szirmai (1944), due to CMV infection. At the moment, CMV is the most important pepper pathogen virus in Hungary. The degree of the infection varies from year to year, depending on ecological factors (Tóbiás et al. 1978, Tóbiás \& Molnár, 1983). The majority of the tested pepper varieties proved to be susceptible or at least tolerant (Zatykó, 1982). Six varieties (Édesalma, Suptol, Szintetikus Cecei, Táltos Synthetic, Boni, Korona) were tolerant to CMV infection (Fehér \& Kristóf, 1995, Fehér, 1996). Grube et al. (1996) developed CMV resistant genotypes and tools for marker-assisted selection (MAS) to facilitate further transfer of CMV resistance.

Among economically important viruses TMV was mentioned at first time by Szirmai (1950). The breeding program against tohamoviruses started with the incorporation of $\mathrm{L}$ genes into commercial pepper varieties. Today many of the pepper varieties contain $\mathrm{L}^{1}, \mathrm{~L}^{2}$ and $\mathrm{L}^{3}$ genes (Gáborjányi et al., 1998b). At present eleven varieties contain the $\mathrm{L}^{1}$ and seven ones (Novares Fl, Rapires Fl, Dabora Fl, Savó Fl, Brill Fl, Cecil Fl, Bölény) the $\mathrm{L}^{2}$ gene (Gáborjányi et al., 1998b). Recently a new variety, Ciklon Fl was reported to have the $\mathrm{L}^{3}$ gene (Sági \& Salamon, 1998). First hybrid $(H / 9-6 F l)$ containing the $\mathrm{L}^{4}$ gene was created first by Csilléry in 1983 using Capsicum chacoense as a source of resistance and a green hot pepper variety (Himes FI), which was registered in 1997 (Salamon, 1997, Sági \& Salamon. 1998).

Before 1968 all the tested varieties were susceptible to TMV, CMV, potato X potexvirus (PVX) and PVY infections (Horváth, 1967, Beczner \& Horváth, 1969, Horváth, 1969). After this time a breeding program was started to built the resistance genes into different pepper varieties (Zatykó, 1982). Resistance of varieties and sources of resistance to viruses was first summarized by Horváth
(1983). In 1985 only $10 \%$, but in $199531 \%$ of the registered Hungarian pepper varieties had some degree of virus resistance (Gáborjányi et al. 1998b).

To know the susceptibility or resistance of the different pepper varieties is of great importance. Therefore the aim of our study was to examine virus susceptibility of 18 varieties to four viruses.

\section{Material and methods}

Seeds of 18 varieties (Cecil Fl, Ciklon Fl, Star, Synthetic Cecei, Tuba, Tizenegyes, Fehérözön Synthetic, Boni, Korona, Brill Fl, Táltos Synthetic, Alba Regia, Gigant F1, Greygo, Édes Alma, Hímes F1, Dabora F1, Rapires Fl) of pepper were sown in sterilized boxes in the virological glasshouse free of vectors. The seedlings were planted in plastic pots (12 cm in diameter) containing a soil mixture of sand ( $\mathrm{pH} 6.96$, humus \% 0.27): peat ( $\mathrm{pH} 6.78$, humus\% 9.98) $1: 3$. Seven plants at 6-8 leaves stages of each varieties/hybrids were mechanically inoculated with four viruses: TMV (isolated from tomato), CMV-U/246 (Schmidt \& Horváth, 1982), Maradona isolate of PVYNTN (Beczner et al., 1984), $\mathrm{H}$ isolate of sowbane mosaic sobemovirus (SoMV). Sörensen phosphate buffer $(\mathrm{pH} 7.2)$ in the ratio $1: 1$ was used for inoculation. The inoculated plants were symptomatologically checked for infection. Five weeks after inoculation the varieties were tested using direct doubleantibody sandwich ELISA (DAS ELISA) method, after Clark \& Adams (1977). Substrate absorbance was measured twenty minutes after adding the substrate at $405 \mathrm{~nm}$ wavelength on Labsystems Multiskan RC ELISA Reader. Out of the seven plants of each variety the highest absorbency values were recorded. Test samples were considered positive if their absorbance values exceeded twice those of the healthy control samples. To confirm the results of serological tests and in latent host-virus relations back inoculation was also carried out to Nicotiana tabacum cv. Xanthi, N. tabacum cv. Samsun, N. glutinosa and Chenopodium quinoa, as indicator plants.

\section{Results and discussion}

Out of the studied varieties five (Tuba, Greygo, Brill Fl, Fehér özön Synthetic, Rapires Fl) were susceptible to CMV infection. Among them Rapires $F l$ was symptomless, while others showed systemic symptoms (leaf deformation, mosaic, vein necrosis, chlorotic rings). 13 varieties were resistant to $\mathrm{CMV}$ infection, similar to results of Fehér \& Kristóf (1995), Moór \& Zatykó (1995) and Fehér (1996) (Table 2). Wang et al. (1998) showed that the CMV resistance of pepper varieties at the seedling stage cannot always represent their resistance at the maturation stage. Generally speaking, resistance to CMV was enhanced from the seedling stage to the maturation stage more in pepper or chilli varieties than in sweet pepper varieties.

In spite of the fact that more Hungarian pepper varieties have some degree of resistance to TMV (Gáborjányi et al., 
Table 2 Reaction of pepper varieties to CMV

\begin{tabular}{|l|l|c|c|}
\hline \multicolumn{1}{|c|}{ Varieties } & \multicolumn{1}{|c|}{ Symptoms* } & Absorbance & Biotest \\
\hline Tuba & $-/ \mathrm{Mo}$, Led, Chl, Ri & 0.225 & + \\
Greygo & $-/ \mathrm{Vn}$, Led, Mo & 0.332 & + \\
Dabora F1 & $-/-$ & 0.191 & - \\
Hímes F1 & $-/-$ & 0.183 & - \\
Syn. Cecei & $-/-$ & 0.116 & - \\
Táltos Synthetic & $-/-$ & 0.179 & - \\
Brill Fl & $-/$ Led & 0.341 & + \\
Fehérözön Synthetic & $-/$ Led, Mo, Vn & 0.638 & + \\
Boni & $-/-$ & 0.126 & - \\
Alba Regia & $-/-$ & 0.106 & - \\
Gigant F1 & $-/-$ & 0.158 & - \\
Korona & $-/-$ & 0.159 & - \\
Édesalma & $-/-$ & 0.190 & - \\
Ciklon F1 & $-/-$ & 0.109 & - \\
Tizenegyes & $-/-$ & 0.123 & - \\
Cecil Fl & $-/-$ & 0.126 & - \\
Rapires F1 & $-/-$ & 0.249 & + \\
Star & $-/-$ & 0.134 & - \\
Positive control & & 0.440 & + \\
Negative control & & 0.110 & - \\
\hline
\end{tabular}

* local/systemic symptoms; Mo, mosaic; Led, leaf deformation; Chl, chlorotic lesions; $\mathrm{Ri}$, ringspot; $\mathrm{V} n$, vein necrosis; -, symptomless

1998b), the proportion of the TMV infected varieties was very high. No varieties showing extreme resistance (immunity) have been found. Only systemic symptoms (leaf deformation, mosaic, vein and top necrosis) have been noted in nine varieties (Tuba, Greygo, Synthetic Cecei, Táltos Synthetic, Boni, Alba Regia, Korona, Tizenegyes, Star) and the extinction values were high, similar to those of the positive control during serological tests. Three varieties (Himes Fl, Gigant FI, Édesalma) showed only local symptoms, but on the basis of serological and biological tests TMV was identified from the systemic leaves. Rapires FI showed no symptoms and TMV could not be detected by serological tests, but during back inoculation TMV was isolated from test plants (local necrotic lesions and systemic mosaic symptoms have been developed on $N$. tabacum cv. Xanthi and $N$. tabacum cv. Samsun, respectively, suggesting the presence of TMV) (Table 3). It can be presumed that TMV occurs only at very low concentration in Rapires F1 hybrid.

Some varieties (Dabora Fl, Brill Fl, Fehérözön Synthetic, Ciklon FI, Cecil FI) showed only local hypersensitive reaction due to TMV infection. Necrotic lesions have been developed on the infected leaves 2-4 days after inoculation, and later the infected leaves dropped, preventing the spreading of the virus inside the whole plants (Table 3). Plant resistance to virus infection expressed in the form of restricted systemic movement of the virus has been described for many other virus-host relations (Nelson et al., 1993, Schaad \& Carrington, 1996, Derrick \& Barker, 1997, Guerini \& Murphy, 1999). However a temperature of $30^{\circ} \mathrm{C}$ or more may overcome hypersensitive reaction (HR) in some host-virus systems. Roggero et al. (1996) reported that continuous high temperature can break the hypersensitivity of Capsicum chinense PI 152225 to tomato spotted wilt tospovirus (TSWV). The experiments reported are of practical interest because cultivated species of Capsicum are
Table 3 Reaction of pepper varieties to TMV

\begin{tabular}{|l|c|c|c|}
\hline Varieties & Symptoms & Absorbance & Biotest \\
\hline Tuba & -/Mo & 0.479 & + \\
Greygo & -/Mo & 0.468 & + \\
Dabora F1 & HR/- & 0.228 & - \\
Hímes F1 & HR/- & 0.635 & + \\
Syn. Cecei & -/Mo & 0.353 & + \\
Táltos Synthetic & -/Mo, Led & 0.748 & + \\
Brill F1 & HR/- & 0.146 & - \\
Fehérözön Synthetic & HR/- & 0.215 & - \\
Boni & -/Mo, Led & 0.476 & + \\
Alba Regia & -/Mo, Led & 0.341 & + \\
Gigant F1 & HR/- & 0.340 & + \\
Korona & -/Mo, Led & 0.352 & + \\
Édesalma & HR/- & 0.328 & + \\
Ciklon F1 & HR/- & 0.136 & - \\
Tizenegyes & -/Vn, Tn & 0.408 & + \\
Cecil F1 & HR/- & 0.129 & - \\
Rapires Fl & -/- & 0.173 & + \\
Star & -/Mo, Led & 0.414 & + \\
Positive control & & 0.507 & + \\
Negative control & & 0.134 & - \\
\hline
\end{tabular}

* local/systemic symptoms; Mo, mosaic; Led, leaf deformation; Vn, vein necrosis; Tn, top necrosis; HR, hypersensitive reaction; -, symptomless

susceptible to TSWV and are generally grown where temperatures often exceed $30^{\circ} \mathrm{C}$.

Because some varieties (Tuba, Synthetic Cecei, Tizenegyes, Greygo) -which formerly had been believed to be resistant to TMV-have been infected with TMV, it could be presumed that the TMV isolate used for infection has resistance breaking characteristics, similar to the $\mathrm{Ob}$ strain of ToMV (ToMV-Ob) (Csilléry \& Ruskó, 1980, Tóbiás et al., 1982, Csilléry et al., 1983) and Italian isolates of TSWV which overcome the hypersensitive response of Capsicum varieties with resistance introgressed from $C$. chinense PI 152225 (Roggero et al., 1999).

All of the tested pepper varieties showed resistance to SoMV, in spite of the fact that this virus previously had been serologically detected from field pepper (Gáborjányi et al., 1997). Neither the inoculated nor the non-inoculated leaves showed symptoms and the virus could not be detected in them by serological and biological tests (Table 4).

Tuber necrotic ringspot disease of potato, caused by the NTN strain of PVY was first described in Hungary by Beczner et al. (1984). PVYNTN produces severe necrotic ring symptoms on the potato tubers and berries, too and has resistance breaking characteristics (Le Romancer \& Kerlan, 1992, Weidemann, 1993, Kus, 1995). In spite of the fact, that this new strain cause severe injuries on potato, only mild mosaic symptoms could be seen on susceptible pepper varieties/hybrids due to PVYNTN . Out of the investigated varieties ten were susceptible. Systemic latent infection have been occurred in case of Himes F1, Rapires Fl and Gigant FI hybrids. Eight varieties (Tuba, Fehérözön Synthetic, Boni, Alba Regia, Korona, Édesalma, Cecil FI, Star) were found to be resistant to PVYNTN (Table 5).

While a number of potyviruses infect pepper only three tobacco etch potyvirus (TEV), pepper mottle potyvirus (PepMoV) and PVY are dominant in Europe and North America. Out of them only PVY has economic importance 
Table 4 Reaction of pepper varielies to SoMV

\begin{tabular}{|l|c|c|c|}
\hline \multicolumn{1}{|c|}{ Varieties } & Symptoms* & Absorbance & Biotest \\
\hline Tuba & $-/-$ & 0.103 & - \\
Greygo & $-/-$ & 0.116 & - \\
Dabora FI & $-/-$ & 0.101 & - \\
Hímes FI & $-/-$ & 0.126 & - \\
Syn. Cecei & $-/-$ & 0.101 & - \\
Táltos Synthetic & -- & 0.111 & - \\
Brill F1 & $-/-$ & 0.118 & - \\
Fehérözön Synthetic & $-/-$ & 0.115 & - \\
Boni & $-/-$ & 0.102 & - \\
Alba Regia & $-/-$ & 0.115 & - \\
Gigant F1 & $-/-$ & 0.106 & - \\
Korona & $-/-$ & 0.111 & - \\
Édesalma & $-/-$ & 0.091 & - \\
Ciklon Fl & $-/-$ & 0.104 & - \\
Tizenegyes & $-/-$ & 0.090 & - \\
Cecil FI & $-/-$ & 0.104 & - \\
Rapires F1 & $-/-$ & 0.100 & - \\
Star & $-/$ & 0.196 & - \\
Positive control & & 0.600 & + \\
Negative control & & 0.105 & - \\
\hline
\end{tabular}

*local/systemic symptoms; -, symptomless

in Hungary. Several resistance genes for potyviruses are known in Capsicum genus. Caranta et al. (1997) reported the molecular mapping of potyvirus resistance factors from pepper line 'Perennial' and an analysis of the genetic basis of multipotyvirus quantitative resistance, which allows us to make comparisons with the location of major genes and quantitative trait loci (QTLs) involved in virus resistance. Dogimont et al. (1996) studied the genetic basis of the broad spectrum resistance to potyviruses in a Mexican pepper line (CM 334) using doubled haploid lines. Segregation analyses indicated that resistance to pepper potyviruses in CM 334 is conferred by two genes. The first one, tentatively named Pr4, is dominant and confers the resistance to all known pathotypes $\mathrm{P}(0), \mathrm{P}(1), \mathrm{P}(1,2)$ of $\mathrm{PVY}$ and to PepMoV. The second one, named Pr.5, is recessive; it confers only the resistance to common strain $\mathrm{P}(0)$ of PVY. Kyle \& Palloix (1997) recently proposed the revision of the nomenclature for genetic loci in Capsicum, governing potyvirus resistance. At present there is clear evidence for four independent loci in Capsicum, each with alleles that confer resistance to viral isolates that belong to one or more of the viruses: PVY, PepMoV and TEV. Other studies determined the mechanism of resistance, e.g. the resistance of $C$. annuum cv. Dempsey to TEV is due to interference with virus RNA accumulation (Deom et al., 1997).

Out of the varieties examined five (Boni, Alba Regia, Korona, Édesalma, Star) were resistant to three viruses (SoMV, CMV and PVYNTN). Only one (Cecil Fl) displayed complex, extreme resistance to SoMV, PVYNTN,$C M V$ and hypersensitive reaction to TMV, therefore this hybrid is very important in pepper growing and breeding for virus resistance.

In our experiments each pepper variety was infected with only one virus. Mixed infections, i.e. infection of a plant by more than one type of virus, occur commonly in nature and may result in a range of effects on the host as well as on the
Table 5 Reaction of pepper varieties to PVYNTN

\begin{tabular}{lccc}
\hline Varieties & Symptoms* & Absorbance & Biotest \\
\hline Tuba & $-/-$ & 0.260 & - \\
Greygo & $-/$ Mo & 0.620 & + \\
Dabora F1 & $-/$ Mo, Led & 0.462 & + \\
Hímes F1 & $-/-$ & 0.623 & + \\
Syn. Cecei & $-/$ Mo, Led & 0.634 & + \\
Táltos Synthetic & $-/ M o$, Led & 0.599 & + \\
Brill F1 & $-/$ Mo, Led & 1.448 & + \\
Fehérözön Synthetic & $-/-$ & 0.143 & - \\
Boni & $-/-$ & 0.145 & - \\
Alba Regia & $-/-$ & 0.163 & - \\
Gigant F1 & $-/-$ & 0.634 & + \\
Korona & $-/-$ & 0.133 & - \\
Édesalma & $-/-$ & 0.161 & - \\
Ciklon F1 & $-/$ Mo & 0.667 & + \\
Tizenegyes & $-/$ Mo & 0.590 & + \\
Cecil F1 & $-/-$ & 0.179 & - \\
Rapires F1 & $-/-$ & 0.854 & + \\
Star & $-/-$ & 0.134 & - \\
Positive control & & 0.837 & + \\
Negative control & & 0.134 & - \\
\hline
\end{tabular}

* local/systemic symptoms; Mo, mosaic; Led, leaf deformation; -symptomless

levels of accumulation and degrees of movement of either of the viruses involved. Of particular interest of these works are those mixed infections in which the restricted ability of one virus to move is alleviated by co-infection with another virus (Fuentes \& Hamilton, 1991, Murphy \& Kyle, 1995). Guerine \& Murphy (1999) showed that in C. annuum cv. Avelar plants co-infected with PepMoV and CMV, PepMoV is able to enter, accumulate in and move within internal phloem, thereby allowing the virus to invade young tissues systemically.

We plan mixed infections in future which can suppress or modify resistance or susceptibility of a given variety to viruses.

\section{Acknowleoigements}

We would like to thank the Office for Academy Research Groups Attached to Universities and Other Institutes and Office of University Educational Applications (No. FKFP 0056/1999) for their financial support.

\section{References}

Beczner L. \& Horváth J. (1969): Virus susceptibility of pepper varieties. $19^{\text {th }}$ Plant Prot. Meeting, Budapest 1969. pp. 121-126.

Beczner L., Horváth J. \& Förster H. (1984): Studies on the etiology of tuber necrotic ringspot disease in potato. Potato Res. 27, 339-352.

Beczner L., Salamon P., Molnár B. \& Vassányi R. (1979): Symptomatological and serological characterization of some Hungarian cucumovirus isolates. Agrártudományi Közlem. 38, 94.

Budai Cs., Dormanns, E., Hatala I., Ilovai Z., Kiss E., Szabó P. Varjas B. \& Zentai Á. (1996): Integrated plant protection in forced pepper. Integrated Growing in Horticulture, Budapest 1996. pp. $98-108$.

Burgyán J. \& Szittya Gy. (1996): Contribution of tombusvirus genes to host specifity and symptom phenotype. $10^{\text {th }}$ Internat. Congr. Virology, Jerusalem (Israel), 1996. p. 115. 
Caranta, C., Lefebvre, V. \& Palloix, A. (1997): Polygenic resistance of pepper to potyviruses consists of a combination of isolate-specific and broad-spectrum quantitative trait loci. Molecular Plant-Microbe Interaction 10, 872-878.

Castagnoli, F., Polverari, A. \& Marte, M. (1997): Behaviour of an accession of Capsicum baccatum var. pendulum towards cucumber mosaic virus. Phytopath. Medit. 36, 154-158.

Clark, M. F. \& Adams, A. N. (1977): Characteristics of the microplate method of enzyme-linked immunosorbent assay for the detection of plant viruses. J. Gen. Virol. 34, 475-483.

Csilléry G. (1983): A contribution to the list of the possible interspecific crosses in Capsicum. $5^{\text {th }}$ EUCARPIA Meeting on the Genetics and Breeding of Capsicum and Eggplant. Plovdiv 1983. pp. 15-18.

Csilléry G. \& Ruskó J. (1980): The control of a new tobamovirus strain by linked to anthocyan in deficiency in pepper (Capsicum annum $)$. $6^{\text {th }}$ EUCARPIA Meeting, Eucarpia Capsicum Working Group 1980. pp. 40-43.

Csilléry G., Tóbiás I. \& Ruskó G. (1983): A new pepper strain of tomato mosaic virus. Acta Phytopath. Hung. 18, 195-200.

Deom, C.M., Murphy, J.F. \& Paguio, O.R. (1997): Resistance to tobacco etch virus in Capsicum annuum: inhibition of virus RNA accumulation. Molecular Plant-Microbe Interaction 10, 917-921.

Derrick, P.M. \& Barker, H. (1997): Short and long distance spread of potato leafroll luteovirus: effect of host genes and transgenes conferring resistance to virus accumulation in potato. J. Gen. Virol. 78, 243-251.

Dogimont, C., Palloix, A., Daubze, A., Marchoux, G., Selassie, K.G. \& Pochard, E. (1996): Genetic analysis of broad spectrum resistance to potyviruses using doubled haploid lines of pepper (Capsicum annum L.). Euphytica 88, 231-239.

Duriat, A.S. 1996. Management of pepper viruses in Indonesia: problems and progress. IARD Journal 18, 45-50.

Edwardson, J. R. \& Christie, R. G. (1997): Viruses Infecting Peppers and Other Solanaceous Crops. University of Florida, Gainesville 1997. $770 \mathrm{pp}$.

Fehér A. (1996): Choosing variety. In: Mártonffy B. (ed), Paprika. OLITOR Szaktanácsadó és Informatikai Szolgálat, Budapest 1996. pp. 68-82.

Fehér A. \& Kristóf E. (1995): Hungarian pepper varieties in the last thirty years. $9^{\text {th }}$ EUCARPIA Meeting on Genetics and Breeding on Capsicum and Eggplant. Budapest 1995. pp. 9-13.

Fletcher, J.T., Wallis, W.A. \& Davenport, F. (1987): Pepper yellow vein, a new disease of sweet peppers. Plant Pathol. 36, 180-184

Fuentes, A.L. \& Hamilton, R.I. (1991): Sunn-hemp mosaic virus facilitates cell-to-cell spread of southern bean mosaic virus in a nonpermissive host. Phytopathology 81, 1302-1305.

Gáborjányi R., Csilléry G., Tóbiás I. \& Jenser G. (1995): Tomato spotted wilt virus: A new threat for pepper production in Hungary. $9^{\text {th }}$ EUCARPIA Meeting on Genetics and Breeding on Capsicum and Eggplant, Budapest 1995. pp. 159-160.

Gáborjányi R., Horváth J., Kovács J. \& Kazinczi G. (1998a): Role of viruses in pepper decline in Hungary. $10^{\text {th }}$ EUCARPIA Meeting on Genetics and Breeding of Capsicum Eggplant, Avignon (France) 1998. pp. 129-132.

Gáborjányi R., Horváth J., Kovács J. \& Kazinczi G. (1998b): Role of virus and phytoplasma infections in pepper decline in Hungary: An overview. Acta Phytopath. et Entomol. 33, 229-236.

Gáborjányi R., Pogány M. \& Horváth J. (1997): Role of viruses in pepper decline. Növényvédelem 33, 181-185.

Green, S. K. \& Kalloo, G. (1994): Leaf curl and yellowing viruses of pepper and tomato: An overview. Techical Bull. No. 21. Asian Vegetable Research and Development Center, Taipei 1994. 51 pp.
Grube, R.C., Zhang, Y., Lackney, V., Prince, J., Murphy, J., Huang, B., Paran, I. \& Kyle, M. (1996): Breeding for cucumber mosaic virus resistance in pepper: phenotypic and molecular marker-assisted approaches. National Pepper Conf., Naples 1996. pp. $24-25$.

Guerini, M.N. \& Murphy, J.F. (1999): Resistance of Capsicum annuum 'Avelar' to pepper mottle potyvirus and alleviation of this resistance by co-infection with cucumber mosaic cucumovirus are associated with virus movement. J. Gen. Virol. 80, 2785-2792.

Horváth J. (1967): Virulenzdifferenzen verschiedener Stämme und Isolate des Kartoffel-Y-Virus an Capsicum-Arten und Varietäten. Acta Phytopath. Hung. 1, 333-352.

Horváth J. (1969): Contributions to the susceptibility of paprika varieties to viruses and the differentiation of paprika pathogen viruses. Növénytermelés 18, 79-88.

Horváth J. (1981): Contributions to the virus susceptibility of plants. I. Solanaceae (Capsicum, Datura, Nicotiana and Scopolia species). Bot. Közlem. 68, 181-185.

Horváth J. (1983): Virus resistance of pepper (Capsicum L.) species and varieties: Review. Kertgazdaság 15, 75-80.

Horváth J. (1986a): Compatible and incompatible relations between Capsicum species and viruses. I. Review. Acta Phytopath. Hung. 21, 35-50.

Horváth J. (1986b): Compatible and incompatible relations between Capsicum species and viruses. II. New compatible hostvirus relations (susceptible plants). Acta Phytopath. et Entomol. Hung. 21: 51-58.

Horváth J. (1986c): Compatible and incompatible relations between Capsicum species and viruses. III. New incompatible hostvirus relations (resistant and immune plants). Acta Phytopath. et Entomol. Hung. 21:59-62.

Kálmán D. \& Gáborjányi R. (2000): Personal communication. Kazinczi G., Kadlicskó S. \& Horváth J. (1998a): The effect of Macrophomina phaseolina (Tassi) Goid. and two viruses on pepper (Capsicum annuum L.). Acta Phytopath. et Entomol. 33, 61-68.

Kazinczi G., Horváth J. \& Kadlicskó S. (1998b): The effect of Macrophomina phaseolina (Tassi) Goid. and two viruses on the nutrient content of pepper (Capsicum annum L.) leaves. Acta Phytopath. et Entomol. 33, 305-311.

Kazinczi G., Gáborjányi R., Horváth J. \& Kadlicskó S. (1998c): Etiology of pepper decline. Georgikon Days, Keszthely 1998. pp. 254-259.

Kiss E. (1996): Virus diseases of greenhouse pepper in SouthHungary. Intenational Workshop on Biological and Integrated Pest Management in Greenhouse Pepper, Hódmezôvásárhely (Hungary) 1996. pp. 119-131.

Kus, M. (1995): The epidemic of the tuber necrotic ringspot strain of potato virus Y (PVYNTN) and its effect on potato crops in Slovenia. Proc. $9^{\text {th }}$ EAPR Virology Sect. Meeting, Bled (Slovenia) 1995. pp. 159-160.

Kyle M.M. \& Palloix A. (1997): Proposed revision of nomenclature for potyvirus resistance genes in Capsicum. Euphytica 97, 183-188.

Lane, R.P., McCarter, S.M., Kuhn, C.W. \& Deom, C.M. (1997): 'Dempsey', a virus- and bacterial spot-resistant bell pepper. HortSci. 32, 333-334.

Le Romancer, M. \& Kerlan, C. (1992): Potato tuber necrotic ringspot disease: genetical approach of the phenomenon and studies about hypersensitive or extreme susceptible behaviour of several cultivars. EAPR Virology Section Meeting, Vitoria-Gasteiz 1992. pp. 91-95.

Martelli, G.P. \& Quacquarelli, A. (1983): The present status of tomato and pepper viruses. Acta Hort. 127, 39-64. 
Mijatovi, M. (1997): New pepper lines selected for resistance to tobacco mosaic virus. Acta Hort. 462, 203-209.

Moór A. \& Zatykó L. (1995): Results of pepper breeding in Hungary. Acta Hort. 412, 88-91.

Murphy, J.F. \& Kyle, M.M. (1995): Alleviation of restricted systemic spread of pepper mottle potyvirus in Capsicum annuum cv. Avelar by co-infection with a cucumovirus. Phytopathology 85 , 561-566.

Nelson, R.S., Li, G., Hodgson, R.A., Beachy, R.N. \& Shintaku, M.H. (1993): Impeded phloem-dependent accumulation of the masked strain of tobacco mosaic virus. MPMI 6, 45-54.

Pickersgill, B., Heiser, C.B. \& McNeill, J. (1979): Numerical taxonomic studies on variation and domestication in some species of Capsicum. In: Hawkers, J.G., Lester, R.N. \& Skelding, A.D. (eds), The Biology and Taxonomy of the Solanaceae. Acad. Press, London 1979. pp. 679-700.

Rast, A.T. (1988): Occurrence of pepper yellow vein in the Netherlands. Neth. J, Plant Pathol. 94, 311-313.

Roggero, P., Lisa, V., Nervo, G. \& Pennazio, S. (1996): Continuous high temperature can break the hypersensitivity of Capsicum chinense 'PI 152225 ' to tomato spotted wilt tospovirus (TSWV). Phytopath. Medit. 35, 117-120.

Roggero, P., Melani, V. \& Ciuffo, M. (1999): Two field isolates of tomato spotted wilt tospovirus overcome the hypersensitive response of a pepper (Capsicum annum ) hybrid with resistance introgressed from C. chinense PI 152225. Plant Dis. 83, 965.

Sági Zs. \& Salamon P. (1998): Incorporation of $\mathrm{L}^{4}$ resistance gene into white types of pepper varieties. Plant Breeding Days, Budapest 1998 p. 117.

Salamon P. (1996): Some little-known and newly-emerged viral diseases in pepper (Capsicum annuum L.) produced under cover in Hungary. Intenational Workshop on Biological and Integrated Pest Management in Greenhouse Pepper, Hódmezôvásárhely (Hungary) 1996. pp. 145-151.

Salamon, P. (1997): Differentiation of pepper pathogen tobamoviruses and the main points of their control. $1^{\text {st }}$ International Plant Prot. Conf. Debrecen 1997. pp. 44-45.

Salamon P. \& Némethy Zs. (1995): Pathophysiological and serological properties of some isolates of tobacco rattle virus. Plant Prot. Days, Budapest 1995. p. 107.

Salamon P. \& Szürke J. (1990): Mechanical transmission of the causeal agent of the pepper yellow vein mosaic disease. Növényvédelem 26, 267.

Salamon P., Beczner L. \& Hamilton, R.I. (1987): Dulcamara yellow fleck virus a new member of tobamovirus group isolated in Hungary. $7^{\text {th }}$ Int. Congr. of Virology, Edmonton 1987. p. 329.
Salamon P., Molnár A. \& Beczner L. (1980): Virus diseases of Capsicum annuum increasing importance of some recently isolated viruses in Hungary. $8^{\text {th }}$ Conf. Czechoslovak Plant Virologists, Bratislava 1980. pp. 421-429.

Schaad, M.C. \& Carrington, J.C. (1996): Suppression of longdistance movement of tobacco etch virus in a nonsusceptible host. J. Gen. Virol. 70, 2556-2561.

Schmidt, H.E. \& Horváth J. (1982): Occurrence of cucumber mosaic virus on bean plants (Phaseolus vulgaris L.) in Hungary. $28^{\text {th }}$ Plant Protection Days, Budapest 1982. p.3.

Sowell, G. (1982): Resistance to tobacco mosaic virus in pepper introductions. Plant Disease 66, 1062-1064.

Sudarsono, C., Sari, N. \& Suseno, R. (1998): Response of ten hot pepper lines to infection of CMV or PVY. Capsicum and Eggplant Newsletter 17, 57-60.

Szirmai J. (1941): About the virus disease, called "újhitûség", causing pepper decline. Növényvédelmi Kutatóintézet. Növényegészségügyi Évkönyv, Budapest (1937-1939).1, 109-133.

Szirmai J. (1944): Virus diseases of pepper. Növényvédelem 1, 51-55.

Szirmai J. (1950): Viruses and virus diseases. In: Ubrizsy, G. (ed), Plant Pathology. Akadémiai Kiadó, Budapest 1952. pp. 193-232.

Szittya Gy. \& Burgyán J. (1996): Localization of tomato bushy stunt virus genes responsible to host specifity. $10^{\text {th }}$ Internat. Congr. Virology, Jerusalem (Israel) 1996. p. 120.

Tóbiás I. \& Molnár A. (1983): Virus symptoms and viral pathogens occuring in pepper in Hungary. Kertgazdaság 15, 49-55.

Tóbiás I., Molnár A., Salamon P. \& Beczner L. (1978): Effect of virus infections on some sweet pepper varieties. Kertgazdaság 3, $51-60$.

Tóbiás I., Rast A.T. \& Maat, D.Z. (1982): Tobamoviruses of pepper, eggplant and tobacco: comparative host reactions and serological relationships. Neth. J. Pl. Path. 88, 257-268.

Wang, S., Pissawan, C. \& Yang, C.Y. (1998): Evaluation of pepper (sweet pepper) resistance to cucumber mosaic virus 15 (Thai-isolate) at seedling and maturation stages of plants. Jiangsu J. Agr. Sci. 14, 21-26.

Weidemann, H.L. (1993): Necrotic ring symptoms on potato tubers. A new strain of potato virus $\mathrm{Y}$ as cause. Der Kartoffelbau 44, 308-309.

Zatykó L. (1982): Pepper cultivation. Mezôgazdasági Kiadó, Budapest $1982.388 \mathrm{pp}$. 